\title{
Quantification and characterization of cocoa pod husks for electricity generation in Uganda
}

\author{
George Kilama ${ }^{1,2}$, Peter O. Lating ${ }^{1}$, Joseph Byaruhanga ${ }^{1}$ and Saphina Biira ${ }^{3 *}$
}

\begin{abstract}
Background: Due to limited coverage, the electricity power supply in Uganda is an obstacle to the country's economic development. Utility firms in Uganda either lack the financial capacity to expand their grids to isolated rural areas or choose not to do so due to the low return on investment. Therefore, connecting households to minigrids represents an effective solution to providing power to remote/rural areas. This study evaluates the resource and technology of generating electrical energy from cocoa pod husks (CPHs), an agricultural residue/waste, generated in Uganda. The use of agricultural waste for energy generation is the most suitable option for the rural population in Uganda because of the availability of a raw material (biomass) for its production, which is pollutionfree (renewable and clean) and does not have competition for use. The inability to convert these solid wastes into useful products culminates into environmental related challenges, such as landfilling, climate change, pests, and diseases. Therefore, the aim of this study is to quantify the amount of generated CPHs and evaluate its potential for electricity generation in Uganda. Subsequently, we have been looking into the potential of CPHs as a feedstock for a thermochemical conversion process and the feasibility of a direct combustion technology.

Results: The amount of CPHs generated in Uganda has been estimated. The physiochemical analysis has shown that the proportion of CPHs in the fresh pods is about $74 \%$, which is nearly the same as in other studies. The dry matter content of CPHs has been found to be on an average of 19\%, whereas ash content, moisture content, and the gross caloric value have been recorded to be $12.3 \%, 12.58 \%$, and $17.5 \%$, respectively. It seems therefore likely that $41.7 \mathrm{GJ}$ of energy might be produced each year from CPHs in Uganda.

Conclusion: This study has demonstrated that the $\mathrm{CPHs}$ are an important energy source. As there is an increasing trend in cocoa and CPH production in Uganda per year, the electricity production based on CPHs is sustainable and can be upgraded. The use of CPHs for energy conversion is therefore feasible, cost-efficient, and a solution to some environmental challenges.
\end{abstract}

Keywords: Cocoa pod husks, Electricity generation, Biomass, Uganda

\section{Background}

Energy is an essential need for mankind and the driving force for the development of all sectors. Electricity remains a critical aspect for Uganda with regard to the growth capacity and socio-economic transformation of its fast growing population. Currently, about $10 \%$ of Uganda's population have access to electricity [1]. Uganda still ranks among the lowest in Africa in terms

\footnotetext{
* Correspondence: bsaphina@yahoo.co.uk

${ }^{3}$ Department of Physics, Busitema University, Tororo, Uganda

Full list of author information is available at the end of the article
}

of access to electrification with $90 \%$ of the population depending on biomass (in the form of firewood and charcoal), which leads to deforestation, climate change, and loss of biodiversity $[2,3]$.

Due to increased national energy demand, diminishing fuel reserves in the world (leading to increasing fuel costs), enhanced environmental concerns, depleting hydropower plant sites, and waste management challenges [4], the need to find alternative renewable energy sources is indispensable. It is important to note that hydroelectricity power generation is facing the challenge of sinking water levels in lakes and a depletion of the 
available sites due to the continuously rising power demand. In this case, renewable energy technologies might help countries to meet their policy goals for secure, reliable, and affordable energy and expand electricity supply among the population to promote its development. Up-to-date and reliable information on the costs and performance of renewable energy technologies might be able to assist governments in rendering decisions on the choice of renewable energy technologies (which are most appropriate for a particular circumstance and place). In this study, we examine the possibility of generating electricity from $\mathrm{CPH}$ in Uganda.

Cocoa (Theobroma cacao L.) is a major cash crop of the tropical world, including Uganda. The postharvest processing of cocoa pods into cocoa beans generates a number of by-products that are usually discarded as waste. If an appropriate technology is applied, these 'wastes' could in fact be processed into other cocoa products of economic importance [5]. Among these wastes are cocoa pod husks (CPHs) which constitute about $81 \%$ of the cocoa fruit. At present in Uganda, CPHs are essentially waste products that are left on plantation sites to decompose which leads to several environmental issues, such as pests and diseases. Most of the cocoa produced in Uganda is exported. For example, by December 2015, Uganda exported 26,412 metric tons of dry cocoa beans, fetching total export earnings of about $\$ 72.536$ million [6]. As already mentioned, $\mathrm{CPHs}$ constitute 81 to $90 \%$ of the fresh weight of the cocoa fruit which is discarded as waste, meaning that only about 10 to $19 \%$ by weight of the cocoa fruit is commercialized [7]. Moreover, CPHs pose a waste disposal problem. The continuous deposition of agricultural wastes (including $\mathrm{CPHs}$ ) without transformation to other usable products has resulted in silting, blockage of water drainage systems, flooding of rivers, and water pollution [8]. This problem could be reduced if these wastes were processed into other products such as electric fuels, which is a pressing need for Uganda.

Several studies have been conducted dealing with the conversion of CPHs into useful products, such as pyrolysis oil [9], biochar [10], potash [11], and animals feeds [12]. Only a few studies have quantified and examined CPHs as a potential feedstock for energy generation with respect to the quantity of cocoa beans produced in a particular geographical location. For example, Maleka [13] investigated the feasibility of converting $\mathrm{CPHs}$ into energy by direct combustion, gasification, pyrolysis, anaerobic digestion, and hydrothermal carbonization. Syamsiro et al. 2012 [14] studied the use of $\mathrm{CPH}$ s as a renewable energy source by means of pelletization and carbonization into high-quality solid fuels, whereas in 2015, Martínez et al. [15] assessed the most feasible thermochemical treatment for the energetic valorization of $\mathrm{CPHs}$.

This study is aimed at ascertaining the quantity of $\mathrm{CPHs}$ produced in Uganda and the feasibility of producing electricity from $\mathrm{CPHs}$ generated after harvesting the cocoa pods. To achieve this, the potential of $\mathrm{CPHs}$ as a feedstock for a thermochemical conversion process using direct combustion was evaluated. The feasibility of a direct combustion technology was examined. $\mathrm{CPH}$ use for electricity, if adopted, can contribute to the conservation of non-renewable energy (mostly fossil resources) and provide an independent energy source. Improved electricity supply and distribution in rural areas might create employment and enhance income in the communities. Since the entire $\mathrm{CPH}$ can be used for electricity production, fire and soil erosion risks in the plantations is likely to be reduced. Apart from the cocoa beans, the development of other marketable cocoa products such as the generation of electricity from $\mathrm{CPHs}$ might encourage further growth of the crop and an improvement in the cocoa value chain. Therefore, this study will support efforts towards the generation and application of technologies that will enhance the transformation of Uganda's rural electrification program by the use of biomass-based mini-grids.

\section{Materials and methods \\ Area of study}

In this study, fresh cocoa pods were obtained from selected cocoa gardens in the Bundibugyo District. Bundibugyo District is located at the foot of Mt. Rwenzori in the western region of Uganda. The district is bordered by the Ntoroko District to the north, the Kabarole District to the east and southeast and the Democratic Republic of Congo to the west. The main administrative headquarter of the district is located at $0^{\circ} 49^{\prime} 60^{\prime \prime} \mathrm{N}$, $30^{\circ} 15^{\prime} 0^{\prime \prime} \mathrm{E}$ at an elevation of about $890 \mathrm{~m}$ above sea level [16]. The map of Bundibugyo District is indicated in Fig. 1. The Bundibugyo District was chosen because more than $70 \%$ of the cocoa produced and exported from Uganda originates from that area $[17,18]$.

\section{Sample collection}

Ripe and ready to harvest cocoa pods were purchased from 17 randomly selected farmers from cocoa-growing areas of the Bundibugyo District. The farmers are denoted $\mathrm{A}$ to $\mathrm{Q}$ in Table 1. Of these farmers, 16 provided 10 cocoa pods each, whereas 1 farmer provided 8 cocoa pods totaling 168 pods. These pods were all mixed together. The reasoning for this was that exported cocoa beans are usually mixed together from several farmers. These pods were plucked from the cocoa plant on the day of purchase. The pods were then maintained fresh 


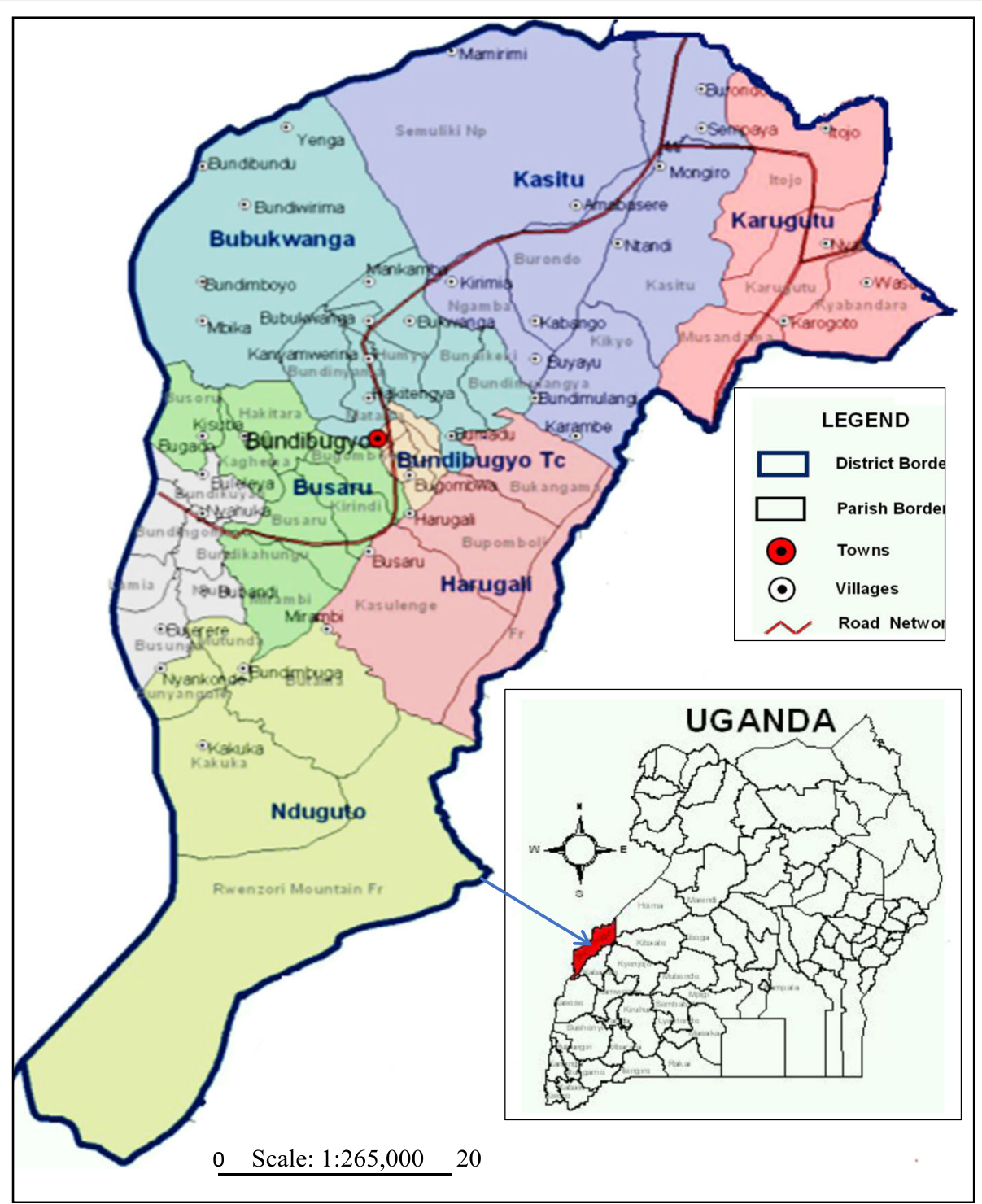

Fig. 1 Map of Bundibugyo [6, 26]

until the moment of cracking (opening the pods). Prior to cracking of the pods and removal of the beans, the pods were weighed using an electronic mass balance with a precision of $0.01 \mathrm{~g}$. After removing the cocoa beans, the mass of the CPHs was determined by weighing the CPHs. The process of cracking and weighing the CPHs is illustrated in Fig. 2.

The percentage weight of the wet $\mathrm{CPHs}$ that were generated by the wet cocoa pods and then determined using Eq. (1) gives

$$
\mathrm{CPH} \%=\frac{M_{h}}{M_{p}} \times 100 \%
$$

where $M_{h}$ is the mass of the wet cocoa pod husk and
$M p$ is the mass of the wet pods before they were opened to remove the beans. The mass of the wet beans from each individual pod was determined by estimating the mass difference between the cocoa pod and the CPHs as given in Eq. (2).

$$
M_{b}=M_{p}-M_{h}
$$

The beans were then collected and put together ready for the fermentation process. The husks were then chopped into small pieces ready for drying. Table 1 presents the values of the weights of 168 pods with their corresponding bean and pod husk masses obtained from each farmer. 
Table 1 Mass of cocoa beans and pod husks

\begin{tabular}{|c|c|c|c|c|c|}
\hline Farmers & Number of pods & Mass of fruits $\left(M_{\mathrm{p}}\right)(\mathrm{g})$ & Mass of $\mathrm{CPHs}\left(M_{\mathrm{h}}\right)(\mathrm{g})$ & Mass of wet beans $\left(M_{\mathrm{b}}\right)(\mathrm{g})$ & $M_{\mathrm{h}} / M_{\mathrm{p}} \times 100 \%$ \\
\hline A & 10 & 4618.3 & 3289.7 & 1328.6 & 71.2 \\
\hline B & 10 & 4540.8 & 3534.8 & 1006.0 & 77.8 \\
\hline C & 10 & 5086.1 & 3827.9 & 1258.2 & 75.3 \\
\hline D & 10 & 4675.8 & 3611.6 & 1064.2 & 77.2 \\
\hline E & 10 & 4160.7 & 3065.3 & 1095.4 & 73.7 \\
\hline $\mathrm{F}$ & 10 & 4100.8 & 2924.4 & 1176.4 & 71.3 \\
\hline G & 10 & 4763.5 & 3507.3 & 1256.2 & 73.6 \\
\hline $\mathrm{H}$ & 10 & 5432.7 & 4223.6 & 1209.1 & 77.7 \\
\hline । & 10 & 4361.6 & 3256.7 & 1104.9 & 74.7 \\
\hline J & 10 & 4056.1 & 2848.5 & 1207.6 & 70.2 \\
\hline K & 10 & 3298.8 & 2393.1 & 905.7 & 72.5 \\
\hline L & 10 & 3438.4 & 2508.6 & 929.8 & 73.0 \\
\hline M & 10 & 3119.5 & 2251.2 & 868.3 & 72.2 \\
\hline N & 10 & 2634.3 & 2011.2 & 623.1 & 76.3 \\
\hline $\mathrm{O}$ & 10 & 3302.3 & 2365.6 & 936.7 & 71.6 \\
\hline$P$ & 10 & 2750.0 & 2002.8 & 675.6 & 72.8 \\
\hline Q & 8 & 1950.7 & 1434.6 & 516.1 & 73.5 \\
\hline Total & 168 & $66,290.4$ & $49,056.9$ & $17,161.9$ & \\
\hline Average & & 394.6 & 292.0 & 102.2 & 73.8 \\
\hline
\end{tabular}

\section{Quantification of cocoa beans and CPHs generated in Uganda}

Uganda Bureau of Statistics data regarding cocoa export For comparison and quantification purposes, the cocoa beans export data were obtained from the Uganda Bureau of Statistics. These data were arranged in four quarters $\left(Q_{1}\right.$ to $\left.Q_{4}\right)$ per year from 2009 to 2015 , as indicated in Table 2. The data obtained from the experiment together with the export data were analyzed to determine the amount of CPHs that are annually generated in cocoa processing in Uganda. Based on the following indicators, the production capacity for $\mathrm{CPHs}$ in Ugandan plantations was estimated.
The fermentation of cocoa beans and their drying process

As the data obtained from this study were compared with the cocoa export data, the cocoa beans collected were processed in a similar way as those exported. These processes include fermentation and drying of the cocoa beans.

The stand-alone, hardwood fermentation boxes with dimensions of $50 \mathrm{~cm} \times 70 \mathrm{~cm} \times 60 \mathrm{~cm}$ were constructed and used for the fermentation process of the sample beans. The boxes incorporated a slatted timber floor and a tray underneath to catch and funnel the 'sweatings.' The timber sides of the boxes were constructed with a 5-mm gap created between boards to allow better

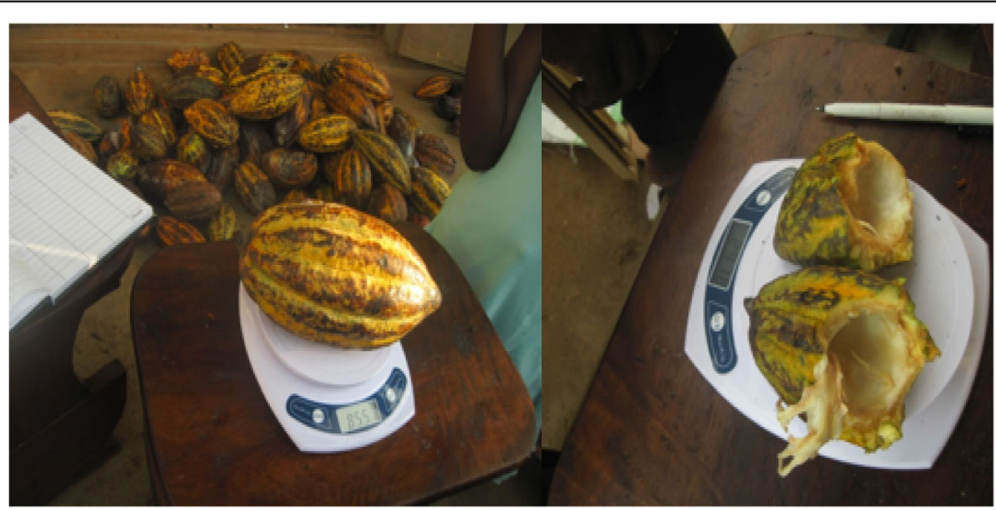

Fig. 2 Cracking and weighing of the CPHs 
Table 2 Quantity of cocoa (in kilograms) exported per year [6]

\begin{tabular}{llllll}
\hline Year & Q1 & Q2 & Q3 & Q4 & Total \\
\hline 2009 & 134,727 & 128,511 & $140,287.68$ & $141,889.78$ & $545,415.5$ \\
2010 & $105,352.9$ & $191,021.51$ & $164,072.92$ & $222,007.4$ & $682,454.7$ \\
2011 & $222,449.7$ & $173,248.01$ & $206,026.7$ & $202,407.78$ & $804,132.2$ \\
2012 & $244,027.92$ & $233,553.3$ & $264,790.9$ & $304,868.98$ & $1,047,241$ \\
2013 & 271,543 & $189,161.97$ & $225,969.54$ & 250,486 & $937,160.5$ \\
2014 & $3,824,542$ & 643,641 & $9,544,688.4$ & $6,200,250$ & $20,213,121$ \\
2015 & $6,767,300$ & $5,993,641$ & $7,587,768$ & $5,629,036$ & $25,977,745$ \\
Total & $11,569,942.5$ & $7,552,777.79$ & $18,133,604.14$ & $12,950,945.94$ & $50,207,270$ \\
\hline
\end{tabular}

aeration. These boxes had a capacity to accommodate about $10 \mathrm{~kg}$ of wet beans. The wet beans were placed in these boxes and covered with jute sacks. These loaded fermentation boxes were elevated from the ground with supports on each bottom corner of the boxes to allow for enough aeration and free flow of the 'sweating.' The beans in the boxes were continuously mixed at an interval of every $4 \mathrm{~h}$ throughout the fermentation process in order to ensure uniformity of the fermenting process of the beans. A temperature probe connected to a multimeter was inserted into the middle of the fermenting beans in the box to monitor temperature changes during the fermentation process to provide an indication of whether fermentation was proceeding properly and later on to determine an endpoint. The latter was determined at a point when the temperature of the fermenting beans became steady. This temperature and $\mathrm{pH}$ that are of importance to the process were found to be $39^{\circ} \mathrm{C}$ and 3.65 , respectively. Their values were measured using the portable waterproof $\mathrm{pH} / \mathrm{EC} / \mathrm{TDS}$ meter (model H1991301, manufactured by Hanna instruments, Romania) and a temperature probe connected to a digital multimeter (model: all sun EM5510 authorized by Global meter, Zhangzhou Eastern Technology Group), respectively. The fermentation process that is illustrated in Fig. 3 took an average of $120 \mathrm{~h}$ (5 days).
After the completion of the fermentation process, the beans were removed from the boxes and sun-dried. During the drying process, the beans were constantly mixed and turned to ensure uniform drying. The moisture content of the drying beans was measured at every interval using the Dickey John Mini GAC Plus Grain moisture tester (model: MINIGACIP, USA) shown in Fig. 4. Drying was stopped when the moisture content was measured to be $12 \%$. All other beans were assumed to be dry when their moisture content was measured to be $12 \%$. The dry beans were then weighed and stored for further analysis and processing.

\section{Moisture content in cocoa pod husks}

The CPHs were chopped into small slices and weighed using a digital mass meter. The mass $M_{1}$ of the fresh $\mathrm{CPH}$ was recorded. The weighed sample was sun-dried and weighed again using a digital mass meter. Thereafter, the mass $M_{2}$ of the dry sample was recorded. The percentage weight loss of the CPHs (moisture content) after drying was calculated using Eq. (3)

$$
\begin{aligned}
& \text { Weight loss of the } \mathrm{CPH}(\%) \\
& =\left(\frac{M_{1}-M_{2}}{M_{1}}\right) \times 100 \%
\end{aligned}
$$

where $M_{1}$ denotes the mass of wet $\mathrm{CPHs}$ and $M_{2}$ denotes the mass of the dry $\mathrm{CPH}$.
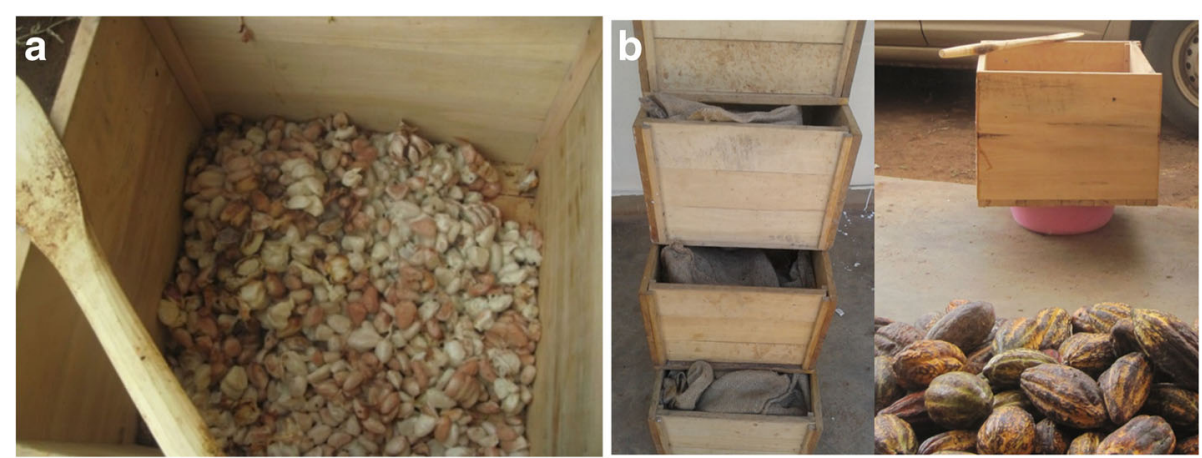

Fig. 3 a Fresh cocoa beams in the fermentation box. b Fermentation process 


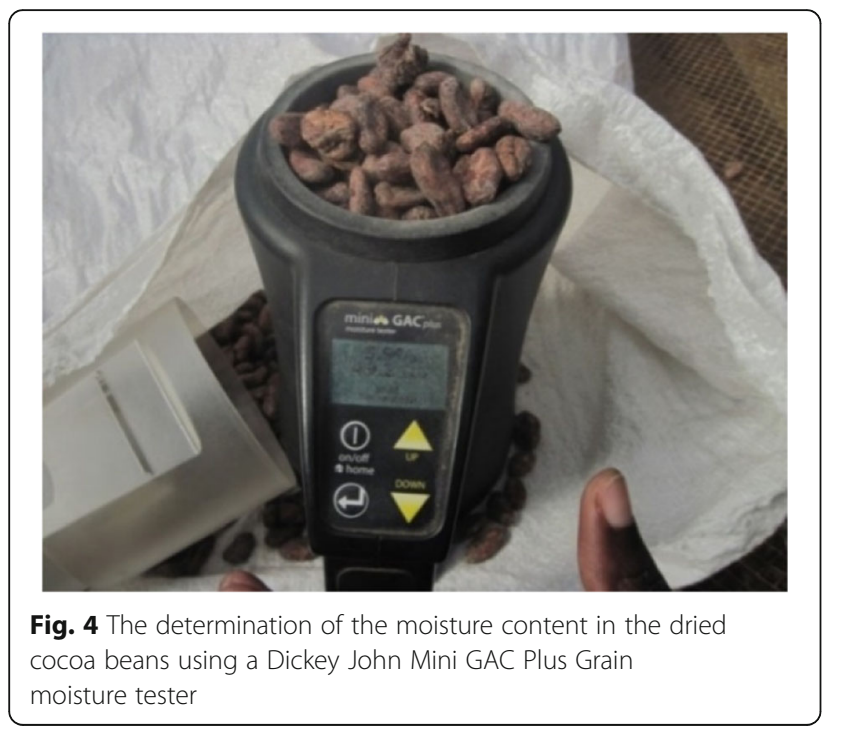

This procedure was repeated at intervals of $1 \mathrm{~h}$ until the required moisture content of $14 \%$ was attained. This calculated average moisture content of $14 \%$ was found to be in the same range as that reported by Luis Velazquez of $13 \%$ [19].

\section{Results and discussion}

\section{The amount of cocoa beans exported}

The analysis of the data obtained from UBOS (see Table 2) indicated that cocoa beans export increased from $545,415.5 \mathrm{~kg}$ in 2009 to $25,977,745 \mathrm{~kg}$ in 2015 . The third and fourth quarter of the year showed the highest export as shown in Fig. 5 due to an increase in the world price index. This export data conformed to a polynomial curve of order 3 with $R^{2}$ greater than 0.9 as demonstrated in Fig. 6a. From 2009 to 2012, there was very little increase in cocoa beans exported. Therefore, this part of the data was not used for further analysis. From 2012 to 2015, cocoa bean export trend increased linearly (see Fig. 6a, b). This might have been due to an increase in farm gate price, rural infrastructure improvement, property ownership, land policy, empowerment of women, better agricultural extension services, and networking (access to telephones and internet). This is an indication that cocoa bean production and thus the capacity to generate significant $\mathrm{CPHs}$ is constantly on the rise in Uganda. Therefore, there is also an increased potential for the production of cocoa and cocoa waste-based products.

\section{The amount of CPHs generated}

Using the data obtained from UBOS (see Table 2) and the experimental results (see Table 1), the quantity of cocoa beans produced per annum was estimated. From Table 1, it is evident that from 168 cocoa pods $49.1 \mathrm{~kg}$ of $\mathrm{CPHs}$ and $17.2 \mathrm{~kg}$ of wet beans were produced which resulted in an approx. $74 \%$ average percentage mass of $\mathrm{CPHs}$ when compared to the total mass of the cocoa pod. Therefore, on average, from every cocoa pod 0.292 $\mathrm{kg}$ and $0.102 \mathrm{~kg}$ of $\mathrm{CPHs}$ and wet beans, respectively, were produced.

From the results indicated in Table 1, it was concluded that 168 pods generated $20.3 \mathrm{~kg}$ of wet beans. When the beans were dried to a $12 \%$ moisture content, $12.15 \mathrm{~kg}$ of dry cocoa beans were generated. Therefore, $1.67 \mathrm{~kg}$ of

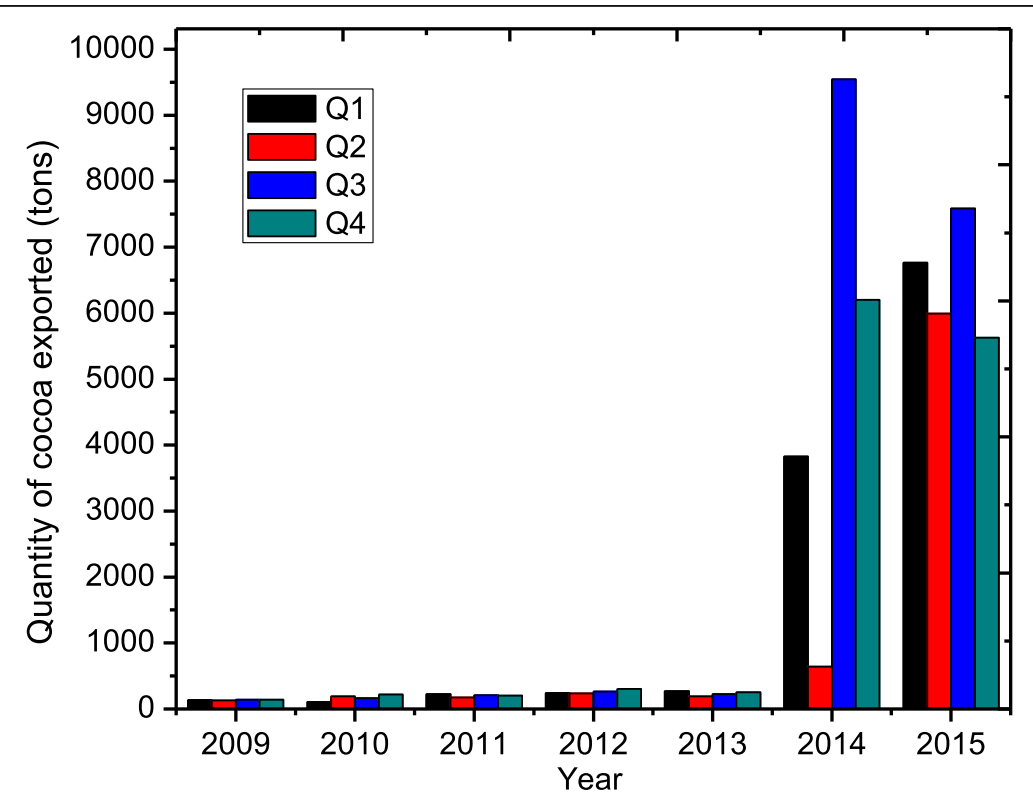

Fig. 5 Quarterly export variation of cocoa beans 

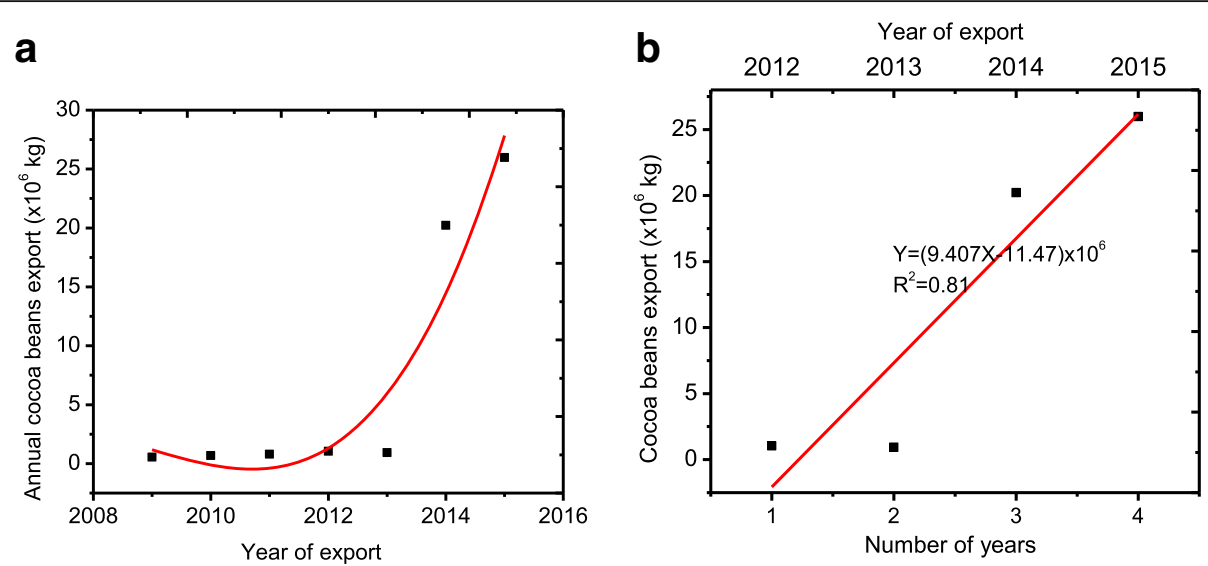

Fig. 6 The over all annual increase in export of cocoa beans in Uganda from 2009 to 2015 followed a polinomial trend (a), with the annual cocoa beans export from 2012 to 2015 showing a linear increasing trend (b)

wet cocoa beans generated $1.0 \mathrm{~kg}$ of dry beans at a moisture content of $12 \%$. Additionally, the $49.1 \mathrm{~kg}$ of wet $\mathrm{CPHs}$ were reduced to $4.24 \mathrm{~kg}$ of dry CPHs with a moisture content of $14 \%$, implying that $1.0 \mathrm{~kg}$ of dry CPHs was generated from $11.6 \mathrm{~kg}$ of wet CPHs. The mass of dry $\mathrm{CPHs}$ that might be generated from $1.0 \mathrm{~kg}$ of dry beans was determined by dividing the mass of dry $\mathrm{CPHs}$ by the corresponding mass of dry beans (i.e., 4.24/ $12.15=0.349 \mathrm{~kg}$ of dry $\mathrm{CPH}$ ). Table 3 lists the summary of the cocoa bean and $\mathrm{CPH}$ production.

The generated annual mass of dry $\mathrm{CPH}\left(\mathrm{CPH}_{d}\right)$ was calculated using Eq. (4).

$$
\mathrm{CPH}_{d}=\mathrm{CB}_{d} \times \mathrm{CB}_{d 1}
$$

where $\mathrm{CB}_{d}$ represents the mass of dry cocoa beans produced in a given year while $\mathrm{CB}_{d 1}$ denotes the mass of dry $\mathrm{CPH}$ generated from $1.0 \mathrm{~kg}$ of dry beans. The latter was determined by dividing the mass of dry $\mathrm{CPH}$ by the corresponding mass of dry beans. Since the export of cocoa beans was observed to increase annually, the

Table 3 Masses of the wet cocoa pods, CPHs, and wet cocoa beans

\begin{tabular}{ll}
\hline Item & Quantity \\
\hline Average weight of a cocoa pod & $384.6 \mathrm{~g}$ \\
Average weight of wet beans in a cocoa pod & $102.2 \mathrm{~g}$ \\
Average weight of wet cocoa pod husks & $292.0 \mathrm{~g}$ \\
Percentage of pod husks by weight of wet pods & $73.8 \%$ \\
Percentage of wet beans by weight of wet pods & $26.2 \%$ \\
Mass of wet beans & $17,161.9 \mathrm{~g}$ \\
Mass of wet pods & $66,290.4 \mathrm{~g}$ \\
Mass of dry CPHs & $4242 \mathrm{~g}$ \\
Mass of dry beans & $12,150 \mathrm{~g}$ \\
Mass of dry CPHs per kg of dry beans & 0.349 \\
\hline
\end{tabular}

cocoa export data of 2015 were used for the rest of the calculation. From the export data, 25,978,245 kg of dry cocoa beans were exported in 2015. Therefore, the mass of dry CPHs generated in 2015 was found to be $9,092,385.75 \mathrm{~kg}$. Using the linear equation illustrated in Fig. 3b, the dry CPHs for the years 2016, 2017, and 2018 were predicted as is shown in Table 4.

\section{Determination of the amount of heat dissipated by the combustion of $\mathrm{CPH}$}

The CPHs were first sun-dried for $96 \mathrm{~h}$ to decrease the moisture content to $14 \%$. In order to obtain the appropriate size of the material for the milling stage, the CPHs were crushed in a hammer mill into smaller particles for easy use in a ball mill. The ball-milled CPHs were then screened to obtain a powder with a grain size of less than $1 \mathrm{~mm}$, according to Syamsiro et al. [20]; the ratio of the surface area of the pellet mass is the most important parameter for the combustion reaction. The weight of the sample used in the calorimeter crucible ranged between $0.8 \mathrm{~g}$ and $1.0 \mathrm{~g}$. During the measurements, oxygen was supplied at a constant pressure of 44 bars. Table 5 shows the amount of heat energy dissipated by the combustion of the $\mathrm{CPH}$ samples.

The results in Table 5 demonstrate that the average energy generated (the gross caloric value) during combustion of $\mathrm{CPHs}$ at a $14 \%$ moisture content was about $17.5 \mathrm{MJ} / \mathrm{kg}$. The caloric values obtained in this study are comparable to those obtained by other scholars. For

Table 4 Dry CPH production

\begin{tabular}{lll}
\hline Year & Dry cocoa beans $(\mathrm{kg})$ & Dry CPHs $(\mathrm{kg})$ \\
\hline 2015 & $25,978,245$ & $9,092,385.75$ \\
2016 & $35,560,650$ & $12,446,227.50$ \\
2017 & $44,967,400$ & $15,738,590.00$ \\
2018 & $54,374,150$ & $19,030,952.50$ \\
\hline
\end{tabular}


Table 5 Amount of heat energy dissipated by CPH combustion in a bomb calorimeter

\begin{tabular}{llll}
\hline Experiment & $\begin{array}{l}\text { Mass of CPHs used in } \\
\text { crucible }(\mathrm{g})\end{array}$ & $\begin{array}{l}\text { Amount of heat energy dissipated by the combustion of } \\
\mathrm{CPH}(\mathrm{J})\end{array}$ & $\begin{array}{l}\text { Heat energy generated per unit mass of } \\
\mathrm{CPHs}(\mathrm{J} / \mathrm{g})\end{array}$ \\
\hline 1 & 0.809 & 15,615 & $19,301.6$ \\
2 & 0.965 & 15,490 & $16,051.8$ \\
3 & 0.815 & 15,098 & $18,525.2$ \\
4 & 0.999 & 15,957 & $15,973.0$ \\
Average & & & $17,462.9$ \\
\hline
\end{tabular}

example, Velazquez et al. achieved $20.2 \mathrm{MJ} / \mathrm{kg}$ [19] and Syamsiro et al. $17.0 \mathrm{MJ} / \mathrm{kg}$ [14]. Other comparative values are listed in Table 6. The gross caloric value (or the high heat value (HHV)) is the total heat energy released per unit mass of the feedstock at atmospheric pressure and room temperature (i.e., about $20^{\circ} \mathrm{C}$ ) at complete combustion. The proximate analysis and dryash-free-based values reported in other studies are given in Table 6.

\section{Measurement of ash, moisture, and volatile contents of CPHs using TGA}

The ash, moisture, and volatile contents of $\mathrm{CPH}$ were measured using a Thermogravimetric analyzer (TGA), Thermostep (ELTRA version TGA 1.4.2.12). The TGA was also used to determine the mass loss as a function of the temperature. It combines the drying and ashing process with integrated weighing. A total of 20 samples each weighing $5 \mathrm{~g}$ were measured, of which 1 sample was used as a reference. The average values of ash, moisture, volatile, and carbon contents measured by the TGA are presented in Table 7. The main factors affecting the quality of the biomass feedstock are moisture content, ash content, particle size, and density. For instance, high-moisture content in biomass feedstock reduces the energy value of the feedstock. A reduction in the moisture content of the biomass feedstock increases the energy density of the feedstock, and helps reduce the transport costs and may also improve the combustion efficiency. In this study, the moisture content was found to be $12.56 \%$ of the total weight of the dry CPHs. It was also important to determine the ash content as ash might form deposits inside the combustion chamber, which could impair the performance and increase the maintenance costs. Therefore, CPHs with a low ash content of about $12.3 \%$ are an appropriate feedstock for combustion. It is of course known that the size and density of the biomass feedstock influence the rate of heating and drying during the combustion process [24].

\section{Electricity generation using direct combustion}

From the evaluation of the potential of $\mathrm{CPHs}$ as a feedstock for power generation (see Table 5), it was clearly demonstrated that $\mathrm{CPHs}$ are a potential feedstock due to their calorific value estimated to be $17.5 \mathrm{~kJ} / \mathrm{kg}$ on a dry basis. This result is in accordance with that of Yadav et al. [22], who estimated a heating value of $16.68 \mathrm{~kJ} / \mathrm{kg}$ at $48 \%$ moisture and a moisture content of $13 \%$ with a heating value of $17.0 \mathrm{MJ} / \mathrm{kg}$ as reported in [14]. The possible amount of energy for each year that could be produced from $\mathrm{CPHs}$ was calculated as a product of combustion efficiency (and is assumed to be $90 \%$ for stoker steam boilers), where the caloric value of the CPHs $(17.5 \mathrm{MJ} / \mathrm{kg})$ and their quantity produced is depicted in Table 8 . The total heat energy generated that might be converted into electricity depends on the boiler. In this case, it was assumed that only $30 \%$ of the heat produced was converted into electricity. This might have been caused by the installation based on an Organic Rankine Cycle showing a high net electricity yield

Table 6 Proximate and dry-ash-free-based analysis values of $\mathrm{CPH}$ s reported in the literature. C, H, N, S, and O denote the carbonhydrogen, sulfur, and oxygen contents, respectively

\begin{tabular}{|c|c|c|c|c|c|c|c|c|c|c|}
\hline \multicolumn{4}{|c|}{ Proximate analysis } & \multicolumn{6}{|c|}{ Dry-ash-free-basis (W\%) } & \multirow[b]{2}{*}{ References } \\
\hline Volatile matter & Fixed carbon & Ash & Moisture content (\%) & $\bar{C}$ & $\mathrm{H}$ & $N$ & $S$ & $\mathrm{O}$ & $\mathrm{HHV}\left(\mathrm{MJkg}^{-\mathbf{1}}\right)$ & \\
\hline 70.4 & 16.7 & 10.9 & 14 & - & - & - & - & & 17.5 & Current study \\
\hline - & - & - & - & - & - & - & - & - & 19 & {$[20]$} \\
\hline 76.4 & 11.6 & 12 & - & 43.9 & 5.8 & 2.2 & 0.5 & 47.6 & 17.39 & {$[21]$} \\
\hline 59.5 & 24.4 & 16.1 & $13 \%$ & - & - & - & - & - & 17 & [14] \\
\hline 66.6 & 22.9 & 10.6 & - & 53 & 5.9 & 3.4 & 0.2 & 37.5 & 15.89 & [15] \\
\hline- & - & 8 & $48 \%$ & 51.1 & 6 & 3.3 & 0.2 & 39.4 & 16.68 & {$[22]$} \\
\hline- & 15.1 & - & - & 56.9 & - & 0.4 & - & - & 16.1 & [23] \\
\hline
\end{tabular}


Table 7 Values of ash, moisture, and volatiles as well as carbon contents as measures for using TGA

\begin{tabular}{ll}
\hline Property & Average value \\
\hline Weight & 1.57 \\
$\%$ moisture & 12.58 \\
$\%$ volatile matter & 62.51 \\
$\%$ analytical ash & 10.88 \\
\%volatiles on dry basis & 70.35 \\
$\%$ ash on dry basis & 12.26 \\
Mass of moisture (mg) & 1.38 \\
Mass of volatile (mg) & 0.39 \\
Mass of ash (mg) & 0.18 \\
\% fired carbon in sample & 16.74 \\
\hline
\end{tabular}

of 20 to 30\% of the heat generated. The Organic Rankine Cycle has the ability to recover low-grade heat [25]. The stoker grate boiler was chosen, as the biomass convention technology is the most appropriate when cocoa pod husks are used as a feedstock. Table 8 shows a linear increase in the amount of electricity from $1.38 \mathrm{MW}$ in 2015 to $2.90 \mathrm{MW}$ in 2018 due to the predicted increase in the quantity of dry CPHs generated. This means that should the $\mathrm{CPH}$ electricity generation option be fully explored, more power could be accessed and used by the rural communities for various developments and the excess power could be supplied to the main power grid. In order to be effective, appropriate policies have to be developed and implemented.

The government of Uganda should establish policy guidelines for the use of sustainable renewable biomass energy. These guidelines might help recognize the benefits of producing power from biomass to meet the certification criteria. To guarantee payment over a long period of time for every kilowatt hour of electricity from biomass energy fed into the main grid, feed-in tariffs can be implemented. This might be done using the avoidedcost approach. Therefore, those guidelines might be used for promoting development and purchasing renewable energy. The government of Uganda might provide incentives to biomass power plant developers and waive taxes on the importation of biomass power plant equipment (as it is the case for solar batteries and photovoltaic panels) to create a supportive environment for its implementation.
The results of this study demonstrate that biomass has a very good potential for small-scale power generation over a longer period of time. In Uganda, government programs, such as National Agricultural Advisory Services, Operation Wealth Creation, and the Cooperative Societies, have focused on producing high-quality cocoa beans for export in the most efficient possible manner. Little emphasis is placed upon the processing of cocoa (both beans and $\mathrm{CPHs}$ ) into other marketable products. Policy guidelines should be developed by focusing on value addition of the already known products and their wastes and research geared towards developing new products.

\section{Practical implications, challenges, recommendations, and future work}

As already mentioned, the use of $\mathrm{CPHs}$ for power production might encourage farmers to grow more cocoa, increase the access of the rural population to power, and improve their income and their general living conditions. The information and results presented in this study might not only form a basis for considering investment options and further research, but also for the formulation of appropriate government policies and regulations.

The use of $\mathrm{CPHs}$ for power production might improve both the greenhouse gas emission efficiency and the efficiency of material usage, through the use of by-products or wastes and the overall reduction of fossil fuel demand for power production. The greenhouse gases emitted by thermal power plants are mainly carbon dioxides. However, a biomass power plant based on CPHs is carbon neutral. Moreover, no extra land is required for the production of $\mathrm{CPH}$ for power production. Therefore, $\mathrm{CPH}$ power plants are an important option for environmental mitigation and waste management through conversion and energy recovery leading to sustainable waste and environment management.

In Uganda, cocoa is mostly grown in rural areas where the transport and communication networks are poor. Here, farmers have small fragmented pieces of land scatted all over cocoa-growing areas. This was a challenge, in particular, during the collection of the feedstock $(\mathrm{CPHs})$, which is costly in terms of time and labor as well as transport and storage and could adversely affect the overall cost of power production.

Table 8 Data on electricity production using CPHs in Uganda

\begin{tabular}{llllll}
\hline Year & Dry CPHs $(\mathrm{kg})$ & Energy produced (MJ) & Total heat generated for electricity (MJ) & Electricity produced (MWh) & Power plant capacity (MW) \\
\hline 2015 & $9,092,385.75$ & $139,440,828$ & $41,832,248.36$ & $11,620.069$ & 1.3833415 \\
2016 & $12,446,227.50$ & $190,875,345$ & $57,262,603.48$ & $15,906.2787$ & 1.8936046 \\
2017 & $15,738,590.00$ & $241,367,016$ & $72,410,104.87$ & $20,113.918$ & 2.3945141 \\
2018 & $19,030,952.50$ & $291,858,688$ & $87,557,606.26$ & $24,321.5573$ & 2.8954235 \\
\hline
\end{tabular}


Coupled with limited information regarding an appropriate technology (which might be used for the thermochemical conversion of biomass into power) and a lack of appropriate policies and regulations governing biomass energy production, there are also limited data of the amount of biomass generated in Uganda. It is therefore recommended that the government of Uganda should improve the transport and communication networks for facilitating investments in agriculture and other sectors that depend on agriculture. Supporting policies and regulations should be developed and implemented to guide the biomass-energy industry and attract investors. The country should also invest in research in order to obtain supporting information on how to ascertain the feasibility and viability of the industry. For instance, as a future work, the following studies ought to be carried out:

(i) Investigations for establishing the use of pyrolysis and gasification in the field of power generation from biomass in Uganda. For example, co-digestion of CPHs and rice husks (another abundant waste in Uganda) might enable the improvement of biogas production and the efficiency of the plant.

(ii) Techno-economic studies dealing with co-firing of $\mathrm{CPHs}$ and bagasse as well as the effect on the efficiency of thermal plants for clarifying its feasibility.

\section{Conclusions}

This feasibility study focused on the application of cocoa pod husks in Uganda in order to develop a strategy for increasing renewable energy and retrieving value-added by-products. The amount of waste cocoa pod husks generated annually in the project area is abundant, but the capacity of the case study plants was based on 9,092, 385.75 tons per year at a $14 \%$ moisture content. From the evaluation of the potential of $\mathrm{CPHs}$ as a feedstock for energy conversion processes, it was concluded that $\mathrm{CPHs}$ are a high-potential feedstock due to its calorific value $(17.5 \mathrm{MJ} / \mathrm{kg}$ in dry basis) comparable to widely used feedstocks, such as wood $(18.6 \mathrm{~kJ} / \mathrm{kg}$ in dry basis) and bagasse. Other advantages of CPHs as a feedstock are the lack of competition for their acquisition and no extra land requirements for their production, as they were harvested from existing plantations at the project area.

Lastly, the by-products have a high potential for existing markets and the creation of new markets in the country.

\section{Abbreviations}

CPHs: Cocoa pod husks; GCV: Gross caloric value; HHV: High heat value; TGA: Thermogravimetric analyzer; UBOS: Uganda Bureau of Statistics

\section{Acknowledgements}

The Authors would like to acknowledge the funding from NOMA

(Norwegian Agency for Development Cooperation program for Master Studies) for this study.

\section{Authors' contributions}

GK did the data collection and the analysis and drafted the manuscript. POL made contributions to the conception of this paper, especially concerning the approach and objectives. JB made contributions to the text by proofreading and suggestions for improving the consistencies of discussion. SB made substantial contributions to the drafting of the manuscript by her critical reviews and her important participation in the debates as well as final draft of the published version. All in all, the paper was jointly drafted and developed in its entirety by all authors and all authors read and approved the final manuscript.

\section{Funding}

This work was supported by the Norwegian Agency for Development Cooperation program for Master Studies (NOMA).

\section{Availability of data and materials}

Data sharing is not applicable to this article as no datasets were generated or analyzed during the current study.

Ethics approval and consent to participate

Not applicable.

\section{Consent for publication}

All authors read and agreed to publish this article.

\section{Competing interests}

The authors declare that they have no competing interests.

\section{Author details}

${ }^{1}$ Department of Mechanical Engineering, Makerere University, Kampala, Uganda. ${ }^{2}$ Department of Agro-processing Engineering, Busitema University, Tororo, Uganda. ${ }^{3}$ Department of Physics, Busitema University, Tororo, Uganda.

Received: 9 October 2018 Accepted: 26 May 2019

Published online: 13 June 2019

\section{References}

1. AfDB (2015) Uganda rural electricity access project

2. Okello C, Pindozzi S, Faugno S, Boccia L (2013) Development of bioenergy technologies in Uganda: a review of progress. Renew Sust Energ Rev 18:55-63

3. Fashina A, Mundu M, Akiyode $O$ (2018) The drivers and barriers of renewable energy applications and development in Uganda: a review. Clean Technol 1:9-39. https://doi.org/10.3390/cleantechnol1010003

4. Owusu PA, Asumadu-Sarkodie S (2016) A review of renewable energy sources, sustainability issues and climate change mitigation. Cival Environ Eng 3:1-14

5. Ado K, Takeda N, Kikuchi M, Taniguchi Y (2006) The pressure effect on the structure and functions of protein disulfide isomerase. Biochemica et Biophysica Acta (BBA)-Proteins and Proteomics 174:586-592

6. UBOS (2017) The National Population and housing census 2014-Area specific profiles series, Kampala. https://ubos.org/wp-content/uploads/ publications/03_2018Statistical_Abstract_2015.pdf. Accessed 12 Sept 2018.

7. Nfor BK, Forton OT, T a B (2012) Valorization of the byproducts of cocoa production - towards a more sustainable cocoa value chain in Cameroon, pp 1-5

8. Galadima A, Getso Z, Leke L, Almustapha M, Adam I (2011) Domestic water pollution among local communities in Nigeria-causes and consequences. Eur J Sci Res 52:592-603

9. Mansur D, Tago T, Abimanyu H (2014) Conversion of cacao pod husks by pyrolysis and catalytic reaction to produce useful chemicals. Biomass Bioenergy 66:275-285. https://doi.org/10.1016/j.biombioe.2014.03.065

10. Tsai C-H, Tsai W-T, Liu S-C, Lin Y-Q (2018) Thermochemical characterization of biochar from cocoa pod husk prepared at low pyrolysis temperature. Biomass Convers Biorefinary 8:237-243 
11. Oddoye E-O, Agyente-Badu C-K, Gyedu-Akoto E (2013) Cocoa and its byproducts: Identification and utilization. In chocolate in Health and Nutrition. Springer, pp 23-37. Humana Press, Totowa.

12. Adomako D, Osei-Amaning E, Asante EG (1999) Compound animal feeds based on cocoa pod husk. Tropical Science 39:120-123

13. Maleka D (2016) Assessment of the implementation of alternative process technologies for rural heat and power production from cocoa pod husks. KTH Royal Institute of Technology, Stockholm

14. Syamsiro M, Saptoadi H, Tambunan BH, Pambudi NA (2012) A preliminary study on use of cocoa pod husk as a renewable source of energy in Indonesia. Energy Sustain Dev 16:74-77. https://doi.org/10.1016/j.esd.2011. 10.005

15. Martinez-Angel JD, Villamizar-Gallardo RA, Ortiz-Rodriguez OO (2015) Characterization and evaluation of cocoa ( Theobroma cacao L .) pod husk as a renewable energy source. Agociencia 49:329-345

16. Wikipedia (2017) Bundibugyo District. https://en.wikipedia.org/wiki/ Bundibugyo_District . Accessed 20 Oct 2017

17. Longino M (2018). Farmers ask government to set up cocoa factory. Daily Monitor Newspaper. Retrived from https://www.monitor.co.ug/News/ National/Farmers-ask-government-set-up-cocoa-factory/688334-4764396149maqm/index.html. Accessed 5 Oct 2018

18. Lutheran World Relief (2015) Players and stakeholders in the cocoa value chain of Bundibugyo

19. Velazquez-araque L, Cárdenas J (2017) A preliminary study of pelletized Ecuadorian cocoa pod husk for its use as a source of renewable energy. In: Proceedings of the 20th world mult-conference on systems, cybernetics and informatics (WMSCI 2016), pp 29-33

20. Syamsiro M, Saptoadi H, Tambunan BH (2011) Experimental investigation on combustion of bio-pellets from Indonesian cocoa pod husks. Asian J Appl Sci 4:712-719

21. Titiloye JO, Abubaker MS, Odetoye T (2013) Thermochemical characterisation of agricultural wastes from West Africa. Ind Crop Prod 47: 199-203

22. Yadav J, Bharat P, Singh R, Campus T (2015) Study on future prospects of power generation by bagasse, rice husk and municipal waste in Uttar Pradesh. SAMRIDDHI-A. J Phys Sci Eng Technol 2:63-75. https://doi.org/10 18090/samriddhi.v2i2.1606

23. Sahore AD, Afferi JK, Oka L, Abouattier JL, Boua KB (2015) Contribution to the study of the cocoa pod cortex voalorisation. J Glob Biosci 4:3201-3206

24. Ciolkosz D (2010) Renewable and alternative energy fact sheet. Charact biomass as a heat fuel. Penn State Univ Univ Park PA, USA

25. Quoilin S, Van Den BM, Declaye S, Dewallef P, Lemort V (2013) Technoeconomic survey of Organic Rankine Cycle (ORC) systems. Renew Sust Energ Rev 22:168-186

26. https://reliefweb.int/sites/reliefweb.int/files/resources/ 9FB70223F1BE5CA5C12573A80045F021-ocha_REF_uga071204.pdf. Accessed 20 Oct 2017

\section{Publisher's Note}

Springer Nature remains neutral with regard to jurisdictional claims in published maps and institutional affiliations.

Ready to submit your research? Choose BMC and benefit from:

- fast, convenient online submission

- thorough peer review by experienced researchers in your field

- rapid publication on acceptance

- support for research data, including large and complex data types

- gold Open Access which fosters wider collaboration and increased citations

- maximum visibility for your research: over $100 \mathrm{M}$ website views per year

At $\mathrm{BMC}$, research is always in progress.

Learn more biomedcentral.com/submissions 